\title{
Classification of mountain non-forest soils with umbric horizon - a case study from the Tatra Mountains (Poland)
}

\author{
Anna Miechówka*, Paweł Zadrożny, Ryszard Mazurek, Krystyna Ciarkowska \\ Soil Science and Agrophysics Department, University of Agriculture in Krakow, Al. Mickiewicza 21, 31-120 Krakow, Poland \\ * prof. dr hab. inż. A. Miechówka, anna.miechowka@urk.edu.pl, ORCID iD: http://orcid.org/0000-0003-2858-8136
}

Received: 28.11.2020

Accepted: 18.03.2021

Associated editor: W. Szymański

\begin{abstract}
In the soils of non-forest biotopes of the Tatra National Park, derived from acid parent materials, in very cool and moderately cold climatic zones, horizons that meet the criteria adopted for the diagnostic horizon umbric occur very often. The paper compares the taxonomic position of soils in non-forest biotopes of the Tatra National Park with the umbric horizon according to World Reference Base for Soil Resources from 2015 (WRB) and the sixth edition of the Polish Soil Classification from 2019 (SGP). In SGP, the supremacy of the umbrik horizon in the key for determining soil units and a thickness criterion other than in WRB for this horizon ( $\geq 30 \mathrm{~cm}$ ) were assumed. The consequence of this is the participation of various types and subtypes of the studied soils, defined according to SGP, in the groups of soils belonging, according to WRB, to: Umbric Leptosols, Umbric Podzols and Umbrisols. In the Leptosols group there are: typical rankers and humic rankers, in the Podzols group: podzolic umbrisols and humic latent podzolic soils, and in the Umbrisols group: umbrisols and humic regosols. It was proposed to introduce umbrisols as a type in the order of black soils to the soil classification in Poland. Currently, in SGP, umbrisols are one of the subtypes of gray soils, belonging to black soils. It was also suggested that the subtype of humus rankers should include rankers in which the total thickness of the Oh (not meeting the thickness criterion of folik) and A horizons is $20 \mathrm{~cm}$ or more.
\end{abstract}

\section{Introduction}

The diagnostic umbric horizon is defined by the World Reference Base for Soil Resources - WRB (IUSS Working Group WRB, 2015) as a dark-coloured mineral surface horizon at least $20 \mathrm{~cm}$ thick (or $10 \mathrm{~cm}$ if it is directly on a solid rock) characterized by an aggregate structure, relatively high organic matter content and a low base saturation (Table 1). According to WRB, a weighted average is calculated for diagnostic criteria 2 and 3 (Table 1), which is then checked against the diagnostic criteria for the upper $20 \mathrm{~cm}$ profile, or for the entire mineral part of the soil lying on solid rock, massive technogenic material or horizons: cryic, petroduric lub petroplinthic, if they start $<20 \mathrm{~cm}$ from the surface of the mineral soil. The umbric horizon may be found in soils belonging to 12 reference groups: Technosols, Cryosols, Leptosols, Gleysols, Andosols, Podzols, Plinthosols, Nitisols, Ferrasols, Planosols, Stagnosols and Umbrisols (IUSS Working Group WRB, 2015).

In the Polish Soil Classification (2019) - SGP, higher thickness is required for the umbrik horizon $(>30 \mathrm{~cm}$ ) and criterion 3 concerns the entire thickness of the horizon (Table 1). Instead of the degree of base saturation, the $\mathrm{pH}$ is given (criterion 4, Table 1). Soils with umbrik horizon are classified as umbrisols - subtype in gray soils, belonging to the black soils order (Kabała et al., 2019).

The formation of umbric horizon is favoured by the carbonate-free bedrock and the climatic conditions occurring in the mountain areas (high amount of rainfall, low temperature). Therefore, this horizon is often identified in the soils of mountain areas (Balaceanu et al., 1987; Sanesi and Certini, 2005; Drewnik, 2008; Bedrna, 2009; Turrión et al., 2009; Bedrna et al., 2009, 2010; Dlapa et al., 2010; Vasiliniuc et al., 2010; Chodorowski et al., 2012; Hudec and Hreško, 2013; Musielok et al., 2013, 2019; Barannyk, 2016; Jenčo et al., 2018). In soils of the Tatra Mts. the presence of umbric horizon was found in Leptosols (Skiba, 2014), Podzols (Drewnik, 2008; Bedrna, 2009; Dlapa et al., 2010) and Umbrisols (Bedrna, 2009; Bedrna et al., 2009; Dlapa et al., 2010).

The aim of this study was to compare the taxonomic position of non-forest biotope soils of the Tatra National Park with the umbric horizon according to the World Reference Base for Soil Resources (IUSS Working Group WRB, 2015) and the latest - 6th edition of the Polish Soil Classification (2019). 


\section{Occurrence of non-forest biotope soils with umbric horizon in the Polish part of the Tatra Mountains}

A review of the data collected as a result of the implementation of previous research projects (Niemyska-Łukaszuk J., Miechówka A. 1996-1999. Zinc, lead and cadmium in non-forest soils of the Tatra National Park - research project 6 PO4G 004 10; Zadrożny P. 2005. Sulfur accumulation in podzolic soils of the Tatra and Babia Góra National Parks - research project 6 PO4G 004 10) on 317 non-forest soil profiles of the Tatra National Park allowed to conclude that umbric horizon (meeting the criteria defined in WRB) most often occurs in soils derived from acid parent materials, in very cold and moderately cold climatic zones (where the average annual temperature is lower than $2^{\circ}$, and the average annual rainfall exceeds $1500 \mathrm{~mm}$ ). Out of 49 soil profiles with a thickness greater than $20 \mathrm{~cm}$, occurring in such conditions, as many as 29 (thus nearly 60\%) had umbric horizon. The parent material of these soils are usually: deluvial, rubble and moraine deposits containing debris of granodiorites, granites, gneisses, metamorphic slates and quartzites. They occur on slopes with different gradient and exposure, at an altitude of 1580-2210 m a.s.l., in the subalpine belt (18 profiles) and in the alpine one (11 profiles) (Fig. 1), under the high-mountain acidophilic rocky grasslands (9 profiles), bilberry communities (8 profiles), high-mountain tall-herb and tall-grass (6 profiles), Nardus grassland ( 2 profiles), snow patch vegetation (1 profile) or mixed one - containing elements of all the aforementioned communities ( 3 profiles). In the soils formed on carbonate rocks, above the timberline, the umbric horizon was not found (Miechówka, 2000; Miechówka and Drewnik, 2018). In the Tatra glades, it was described only in the Kalatówki Glade (cool floor, average year temperature approx. $4^{\circ}, 10^{\circ} \mathrm{ESE}, 1175 \mathrm{~m}$ a.s.l.), in soils derived from moraine, under vegetation characteristic of a fresh meadow with a predominance of elements from Gladiolo-Agrostietum (Table 4).

\section{Materials and methods}

The studied soils (29 profiles) were described according to the Guidelines for Soil Description (FAO, 2006). The names of the reference soil groups, qualifiers and diagnostic horizons according to WRB, in the text are marked with an italic to distinguish them from sometimes similar names in SGP, which are written in regular fonts. The colour of the soils was determined in a dry and moist state using the Revised Standard Soils Colour Charts (Oyama and Takehara, 1970). Samples taken from all soil horizons, after drying, were sieved through a sieve with a mesh diameter of $2 \mathrm{~mm}$ and subjected to laboratory analyses. The soil texture was determined using the hydrometer method

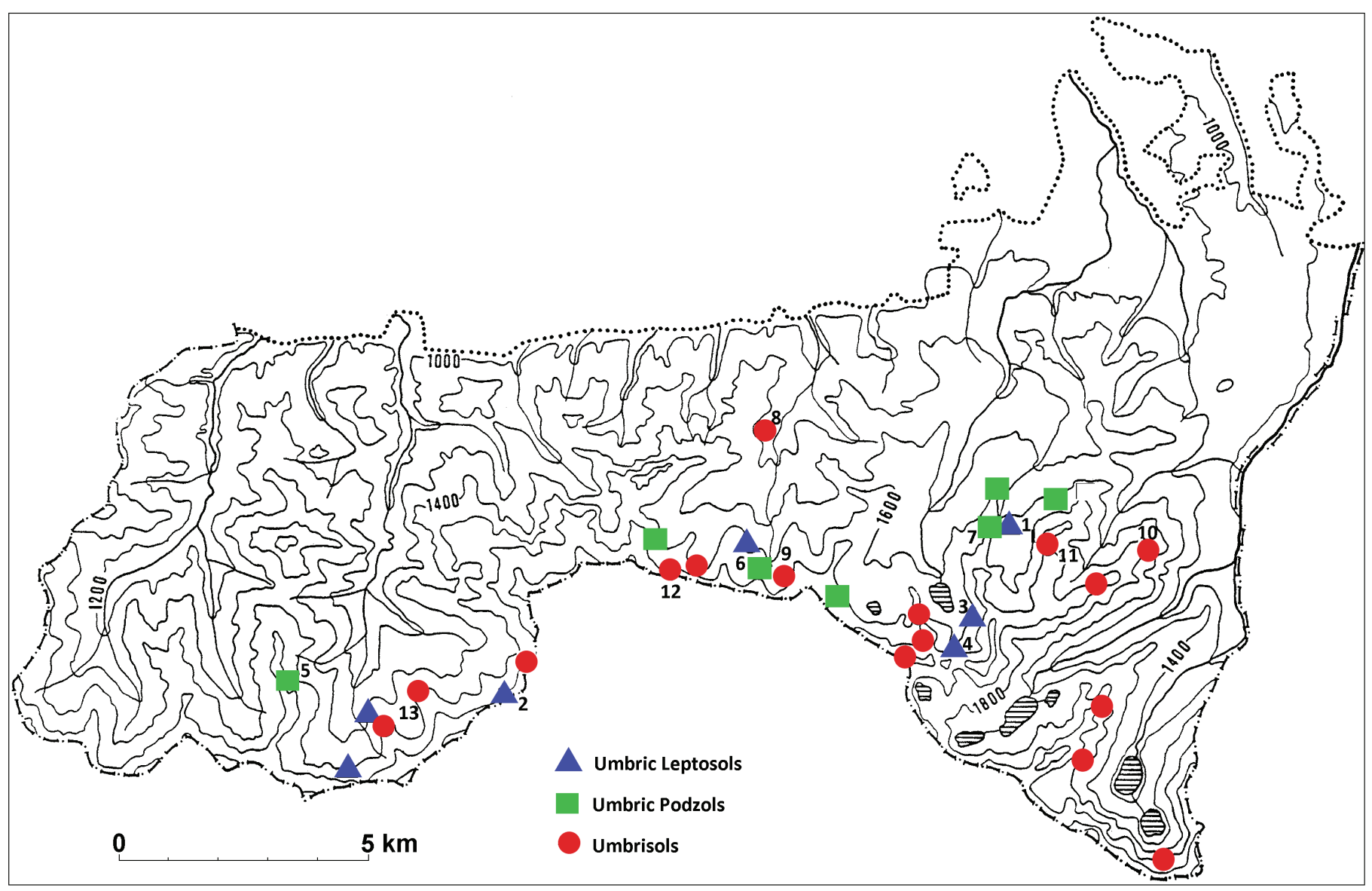

Fig. 1. Location of soil profiles with umbric horizon in Tatra National Park 
Table 1

Criteria for the diagnostic horizon umbric/umbrik by World Reference Base for Soil Resources (IUSS Working Group WRB 2015) - WRB and by the 6 ${ }^{\text {th }}$ edition Polish Soil Classification (2019) - SGP

\begin{tabular}{|c|c|c|}
\hline Diagnostic criteria & Umbric (WRB) & Umbrik (SGP) \\
\hline 1. soil structure & \multicolumn{2}{|c|}{ sufficiently strong, that it is not both massive and hard or very hard, when dry } \\
\hline 2. soil organic carbon in $\%$ & $\begin{array}{l}\geq 0.6 \% \text {, (weighted average) } \\
\geq 0.6 \% \text { (absolute) more soil organic carbon than the } \\
\text { parent material, if parent material is present, that } \\
\text { has a Munsell colour value of } \leq 4, \text { most }\end{array}$ & $\begin{array}{l}\geq 0.6 \% \\
\text { (a weighted average) }\end{array}$ \\
\hline 3. Munsell colour in slightly crushed samples & \multicolumn{2}{|c|}{$\begin{array}{l}\text { value of } \leq 3 \text { moist, and } \leq 5 \mathrm{dry} \text {, and a chroma of } \leq 3 \text { moist; or } \\
\text { a value of } \leq 5 \text { and a chroma of } \leq 3 \text {, both moist, when a texture class of loamy sand or coarser and } \\
\geq 2.5 \% \text { soil organic carbon }\end{array}$} \\
\hline 4. base saturation (by $1 \mathrm{M} \mathrm{NH}_{4} \mathrm{OAc}, \mathrm{pH} 7$ )/ $\mathrm{pH}_{\mathrm{w}}$ & $\begin{array}{l}<50 \% \text { on a weighted average, throughout the entire } \\
\text { thickness of the horizon }\end{array}$ & $\begin{array}{l}\mathrm{pH}_{\mathrm{H} 2 \mathrm{O}}<5,5 \\
\text { (a weighted average) }\end{array}$ \\
\hline 5. thickness & $\begin{array}{l}\text { of one of the following: } \geq 10 \mathrm{~cm} \text { if directly overlying } \\
\text { continuous rock, technic hard material or a cryic, } \\
\text { petroduric or petroplinthic horizon or } \geq 20 \mathrm{~cm}\end{array}$ & $\geq 30 \mathrm{~cm}$ \\
\hline
\end{tabular}

according to PN-R-04032 (Polish Standard, 1998) and described basing on Guidelines for Soil Description (FAO, 2006).

The $\mathrm{pH}$ values were determined potentiometrically in $\mathrm{H}_{2} \mathrm{O}$ $\left(\mathrm{pH}_{\mathrm{H} 2 \mathrm{O}}\right)$ using a standard combined electrode and a CPI-551 $\mathrm{pH}$ meter from Elmetron. Soil organic carbon content (SOC) was determined by the Walkley-Black wet combustion method (modified, with external heating) using $0.1 \mathrm{M} \mathrm{K}_{2} \mathrm{Cr}_{2} \mathrm{O}_{7}$ solution with the addition of concentrated $\mathrm{H}_{2} \mathrm{SO}_{4}$ (Tan, 2005).

The sum of the exchangeable base cations (BC) was measured after extraction of the individual cations $\left(\mathrm{Ca}^{2+}, \mathrm{Mg}^{2+}, \mathrm{K}^{+}\right.$, $\mathrm{Na}^{+}$) with $1 \mathrm{M} \mathrm{NH} \mathrm{NH}_{4} \mathrm{Cl}$ at pH 8.2 using the ICP-OES technique. Hydrolytic acidity (Hh) was determined by the Kappen method (Lityński et al., 1976). The base saturation (BS) was calculated as: $\mathrm{BS}[\%]=\mathrm{BC} /(\mathrm{BC}+\mathrm{Hh}) \times 100$.

\section{Results}

The soils with umbric horizon in the Tatra Mountains contained a significant amount of rock fragments, most often had sand texture (exceptionally loam) and a high content of SOC in the entire soil profile. The SOC content (weighted mean) in the umbric horizons ranged from 3,87 to $17.09 \%$, while in the transition horizons to the rock fragments from 1.62 to $7.81 \%$. All analyzed soils were strongly acid $\left.\mathrm{(pH}_{\mathrm{H} 2 \mathrm{O}} 3.5-5.4\right)$ and characterized by a low base saturation (BS). In soil samples from 28 examined profiles, BS did not exceed $12 \%$, and in two profiles they ranged from 22 to $35 \%$.

According to WRB they were classified into three soil reference groups: Leptosols, Podzols and Umbrisols. The soils belonging to these units differed in thickness (in Leptosols $\leq 23 \mathrm{~cm}$, in Podzols and Umbrisols $\geq 43 \mathrm{~cm}$ ) and in the presence of spodic horizon (it was present in Podzols and not in other soils). In Leptosols a solid rock occurred at the depth of $12-23 \mathrm{~cm}$. The basic properties of exemplary soils belonging to these units are given in Tables 2-4. The values of the parameters characterizing spodic horizons in the examined soils which belonged to Podzols were given in earlier studies (Zadrożny et al., 2007; Zadrożny and Miechówka, 2008).

\section{Discussion}

In the last issue of the SGP, a new type of soil was introduced - gray soils with umbrisols subtype, defined as soils with a developed umbrik horizon. In the classifications of Polish soils previously published in Poland (Polish Soil Classification, 1989, 2011), there was no unit allowing to classify mountain soils with deep, acid humus horizons (Musielok et al., 2013, 2019), corresponding to the Umbrisol unit in the WRB. The introduction of this unit is of great importance for the classification of soils in high mountain areas, where soil patches with umbric horizon occupy large areas. According to preliminary studies by Bedrna et al. (2009) in the Slovak part of the Tatras, about $20 \%$ of the area of the High Tatras, $5 \%$ of the Western Tatras and $1 \%$ of the area of Bielskie Tatras are covered by soils with umbric horizon. These authors, basing on the results of previous studies (Bedrna and Račko, 2000), also suggested that acid or strongly acid surface horizons of rendzinas and pararendzinas in the Bielskie Tatras may meet the umbric horizon criteria. On the Polish part of the Tatra Mountains, one can expect a similar or greater (due to the predominance of northern slopes) share of soils with umbric horizon. However, the studies of non-forest soils on carbonate rocks carried out on the Polish part of the Tatra Mountains have not confirmed the presence of the umbric horizon in them. At higher elevations above sea level, there was a folic horizon, while at lower elevations, a humus horizon that did not meet all the criteria specified for the umbric horizon occurred (Miechówka, 2000; Miechówka and Drewnik, 2018).

Some of the criteria established for the umbrik horizon in SGP differ from those adopted for the umbric horizon by WRB (Table 1). The main difference is the adoption by SGP 
Fig. 2. Number of tested soil profiles representing soils of different types and subtypes according to SGP 2019 classified to: Umbric Leptosols, Umbric Podzols and Umbrisols (WRB 2015)

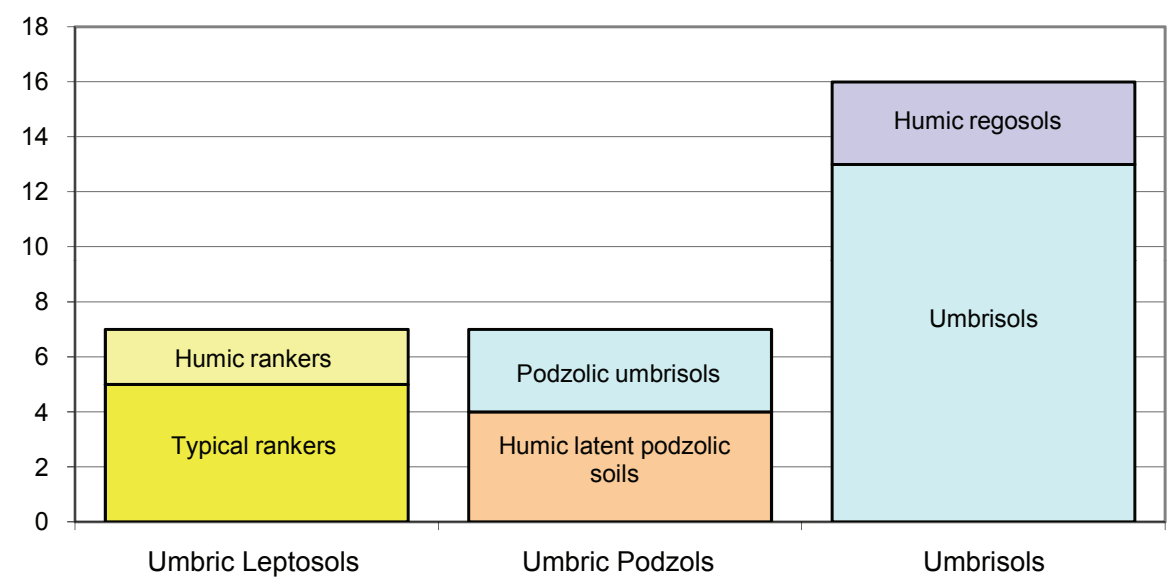

of a higher minimum thickness limit for the umbrik horizon $(30 \mathrm{~cm})$. A very significant difference between SGP and WRB is the different position of umbrisols in the keys given therein for determining soil taxonomic units. According to SGP, all soils with umbrik horizon, including those with a spodik horizon, belong to umbrisols (in the key for orders of soils with umbrik horizon, they are listed earlier than soils with spodik horizon). The consequence of the mentioned differences between the compared classifications is the share of different types and subtypes of the studied soils, defined according to SGP, in the groups of soils belonging to: Umbric Leptosols, Umbric Podzols and Umbrisols according to WRB (Fig. 2).

The soils classified according to WRB to Umbric Leptosols were systematized according to SGP in the order of weakly de- veloped soils, as typical rankers (5 profiles) and humic rankers (2 profiles) (Fig. 2). The humus horizons of these soils met all the criteria of umbrik horizon, with the exception of the thickness - the humic rankers subtype included soils with a thickness of $\mathrm{A} \geq 20 \mathrm{~cm}$, but $<30 \mathrm{~cm}$, and the subtype typical rankers - with a thickness of $\mathrm{A}<20 \mathrm{~cm}$ (Table 2). Due to the similarity of soils represented by profiles 3 and 4 (Table 2), which are classified to different subtypes, it is proposed to mention, in the definition of humic rankers, that also soils, in which the total thickness of Oh (meeting the colour criterion for umbrik and not meeting the thickness criterion for folik) and A horizons is equal or larger than $20 \mathrm{~cm}$, will be included in this subtype.

The soils belonging to Umbric Podzols were classified according to SGP into two different orders - black soils and pod-

Table 2

Basic properties of selected Umbric Leptosols (WRB)

\begin{tabular}{|c|c|c|c|c|c|c|c|c|}
\hline \multirow[t]{2}{*}{ Horizon } & \multirow{2}{*}{$\begin{array}{l}\text { Depth } \\
\mathrm{cm}\end{array}$} & \multicolumn{2}{|c|}{ Colour } & $>2 \mathrm{~mm}$ & \multirow{2}{*}{$\begin{array}{l}\text { Texture } \\
\text { class }\end{array}$} & \multirow[t]{2}{*}{$\mathrm{pH}_{\mathrm{H} 2 \mathrm{O}}$} & SOC & \multirow[t]{2}{*}{ BS } \\
\hline & & dry & moist & $\% \mathrm{v} / \mathrm{v}$ & & & $\%$ & \\
\hline
\end{tabular}

1. Zadni Smreczyński Grzbiet, 1880 m a.s.l., $10^{\circ} \mathrm{NWN}$, Empetro-Vaccinietum, typical ranker*

\begin{tabular}{lllllllll} 
A & $0-9$ & 10YR 3/2 & 10YR 2/2 & 3 & n.a. & 4.0 & 8.87 & 2.0 \\
AC & $9-17$ & 10YR 4/4 & 10YR 3/4 & 60 & LS & 4.5 & 3.45 & 1.3 \\
\hline
\end{tabular}

2. Zawratowy Żleb, $1990 \mathrm{~m}$ a.s.l., 30NE, Salicetalia herbaceae, typical ranker*

\begin{tabular}{lllllllll} 
A & $0-4$ & 10YR 2/2 & 10YR 2/1 & 30 & n.a. & 3.8 & 15.15 & 3.3 \\
AC & $4-14$ & 10YR 4/2 & 10YR 2/2 & 70 & SL & 4.2 & 6.92 & 2.0 \\
\hline
\end{tabular}

3. Kozia Dolina, $1940 \mathrm{~m}$ a.s.l., $30^{\circ} \mathrm{NE}$, Caricetalia curvulae, typical*

\begin{tabular}{lllllllll} 
Oh & $0-9$ & 10YR 3/3 & 10YR 2/1 & 5 & n.a. & 4.3 & 20.26 & 2.8 \\
A & $9-19$ & 10YR 4/2 & 10YR 2/2 & 40 & LS & 4.4 & 5.41 & 1.5 \\
AC & $19-23$ & 10YR 4/3 & 10YR 3/3 & 50 & LS & 4.3 & 4.85 & 1.2 \\
\hline
\end{tabular}

4. Dolina Pańszczyca, 1685 m a.s.l., flat, Hieracio-Nardetum, humic ranker*

\begin{tabular}{lllllllll} 
A & $0-8$ & 10YR 3/1 & 10YR 2/2 & 0 & n.a. & 4.5 & 18.43 & 2.1 \\
AC & $8-23$ & 10YR 3/3 & 10YR 3/1 & 60 & S & 4.8 & 3.83 & 0.9 \\
\hline
\end{tabular}

Explanation: * according to SGP; n.a. - not analyzed; SOC - soil organic carbon; BS - base saturation 
zolic soils. These soils had the spodic/spodik horizon, which is defined in the same way in both classifications. Podzolic umbrisols with well-developed umbrik horizon were included in black soils (in our study: 3 profiles, i.a. 5 and 6, Table 3), while humic latent podzolic soils (in our study: 4 profiles, i.a. profile 7 , Table 3), in which there was no albik horizon and the humus horizon did not meet the thickness criterion for the umbrik horizon, were included in podzolic soils (Fig. 2).

The adoption of different definitions of the umbric/umbrik horizon in the compared soil classifications resulted in the fact that not all of the examined soils belonging to Umbrisols according to WRB were classified in the same way according to SGP (Fig. 2). The soils included in the Umbrisols unit (WRB) and umbrisols (SGP), constitute $40 \%$ of all examined profiles. In the compared classifications, these units are at different hierarchical levels - in WRB they constitute the main unit (the highest level) and in SGP they are a subtype of gray soils, belonging to the order of black soils. They were regarded a priority subtype in SGP (reflected in its unique name umbrisols), but it should be considered whether it would not be better to regard them as a separate type, as in the classification of soils in Slovakia (Bedrna et al., 2009, Societas pedologica slovaca, 2014) or Romania (Florea et al., 2012).

The introduction of the umbrisols type into the Polish soils classification is supported also by the distinctiveness of these soils, expressed by the presence of the umbrik diagnostic horizon (clearly defining these soils), which can only be formed under specific environmental conditions. Moreover, before the 6th edition of SGP was introduced, soils characterized by an acid reaction in the entire profile and the presence of a horizon meeting the umbrik criteria were not traditionally associated with gray soils by soil scientists. Both, gray soils distinguished as a subtype of leached chernozems in the Classification of Forest Soils in Poland (2000), and gray forest soils listed in the rank of type in the class of chernozem soils in the Polish Soil Classification (1974), included soils derived from loess, thus soils with morphological, physico-chemical and trophic properties other than those in the presented umbrisols. Finally, giving umbrisols a rank of type will facilitate the description of acidophilic plant communities that occur on them, because a soil type is a soil classification unit which is the most known and preferably used by phytosociologists.

In the Umbrisols group (WRB), apart from 13 umbrisols (e.g. profiles 8 and 11-13), there were also 3 humic regosols belonging to the order of weakly developed soils (e.g. profiles 9 and 10) (Fig. 2, Table 4). To this group (except for profile 11) high-mountain soils with a similar morphology of the soil profile, having deep humus horizons with a high content of organic carbon, belong. Three out of them were not classified as umbrisols because the lower part of their humus horizons (below $20 \mathrm{~cm}$ ) had a slightly lighter colour than that given as a criterion for the umbrik horizon, in spite of a high content of organic carbon (4.53-12.36\%) in these parts of the horizons.

At the same time, it should be noted that to the umbrisols subtype (SGP) belong soils included in the WRB in both Umbrisols and Umbric Podzols units. Among 14 studied soils

Table 3

Basic properties of selected Umbric Podzols (WRB)

\begin{tabular}{|c|c|c|c|c|c|c|c|c|}
\hline \multirow[t]{2}{*}{ Horizon } & \multirow{2}{*}{$\begin{array}{l}\text { Depth } \\
\mathrm{cm}\end{array}$} & \multicolumn{2}{|c|}{ Colour } & \multirow{2}{*}{$\begin{array}{l}>2 \mathrm{~mm} \\
\% \mathrm{v} / \mathrm{v}\end{array}$} & \multirow{2}{*}{$\begin{array}{l}\text { Texture } \\
\text { class }\end{array}$} & \multirow[t]{2}{*}{$\mathrm{pH}_{\mathrm{H} 2 \mathrm{O}}$} & SOC & \multirow[t]{2}{*}{ BS } \\
\hline & & Dry & Moist & & & & $\%$ & \\
\hline
\end{tabular}

5. Ornak, $1770 \mathrm{~m}$ a.s.l., $45^{\circ} \mathrm{NE}$, Vaccinietum, podzolic umbrisol*

\begin{tabular}{lllllllll} 
Ofh & $0-10$ & 10YR 3/2 & 10YR 2/2 & 0 & n.a. & 3.5 & 33.93 & 7.6 \\
A1 & $10-33$ & 10YR 4/3 & 10YR 3/3 & 10 & n.a. & 3.7 & 7.33 & 3.9 \\
A2 & $33-40$ & 10YR 5/3 & 10YR 4/3 & 35 & S & 4.0 & 4.54 & 2.0 \\
BhsC & $40-60$ & $7.5 Y R ~ 4 / 3$ & 7.5 YR 3/3 & 70 & LS & 4.7 & 3.01 & 1.5 \\
\hline
\end{tabular}

6. Pośredni Wierch Goryczkowy, $1680 \mathrm{~m}$ a.s.l., $45^{\circ} \mathrm{NE}$, Vaccinietum, podzolic umbrisol*

\begin{tabular}{lllllllll} 
A1 & $0-10$ & 10YR 3/1 & 10YR 3/1 & 5 & n.a. & 4.2 & 8.83 & 2.3 \\
A2 & $10-32$ & 10YR 3/4 & 10YR 3/2 & 20 & LS & 4.2 & 7.56 & 1.3 \\
BhsC & $32-50$ & 10YR 4/4 & 10YR 3/2 & 90 & LS & 4.6 & 6.12 & 0.6 \\
\hline
\end{tabular}

7. Żółta Turnia, $1720 \mathrm{~m}$ a.s.l., $50^{\circ} \mathrm{NW}$, Vaccinietum, humic latent podzolic soil*

\begin{tabular}{lllllllll} 
A1 & $0-5$ & 10YR 3/2 & 10YR 2/2 & 5 & n.a. & 3.7 & 17.78 & 4.4 \\
A2 & $5-20$ & 10YR 5/2 & 10YR 4/2 & 20 & LS & 4.4 & 2.55 & 2.5 \\
Es/Bhs & $20-35$ & 10YR 4/2 & 10YR 4/1 & 40 & LS & 4.5 & 2.98 & 2.6 \\
BhsC & $35-55$ & 7.5 YR 3/3 & 7.5YR 2/3 & 70 & LS & 4.6 & 3.13 & 1.5 \\
\hline
\end{tabular}

Explanation: * according to SGP; n.a. - not analyzed; SOC - soil organic carbon; BS - base saturation 
Table 4

Basic properties of selected Umbrisols (WRB 2015)

\begin{tabular}{|c|c|c|c|c|c|c|c|c|}
\hline \multirow[t]{2}{*}{ Horizon } & \multirow{2}{*}{$\begin{array}{l}\text { Depth } \\
\mathrm{cm}\end{array}$} & \multicolumn{2}{|c|}{ Colour } & \multirow{2}{*}{$\begin{array}{l}>2 \mathrm{~mm} \\
\% \mathrm{v} / \mathrm{v}\end{array}$} & \multirow{2}{*}{$\begin{array}{l}\text { Texture } \\
\text { class }\end{array}$} & \multirow[t]{2}{*}{$\mathrm{pH}_{\mathrm{H} 2 \mathrm{O}}$} & $\mathrm{SOC}$ & \multirow[t]{2}{*}{ BS } \\
\hline & & Dry & Moist & & & & $\%$ & \\
\hline
\end{tabular}

8. Kasprowy Wierch, $1770 \mathrm{~m}$ a.s.l., $20^{\circ} \mathrm{NW}$, community with Deschampsia caespitosa, humic regosol*

\begin{tabular}{lllllllll} 
A1 & $0-8$ & 10YR 2/2 & 10YR 2/2 & 0 & n.a. & 4.4 & 19.81 & 1.9 \\
A2 & $8-20$ & 10YR 3/3 & 10YR 3/2 & 5 & n.a. & 4.7 & 15.27 & 0.8 \\
AC1 & $20-41$ & 10YR 6/3 & 10YR 4/4 & 50 & n.a. & 4.9 & 12.36 & 0.6 \\
AC2 & $41-66$ & n.a. & n.a. & 80 & SL & 4.6 & 3.53 & 0.5 \\
\hline
\end{tabular}

9. Turnia nad Dziadem, $1635 \mathrm{~m}$ a.s.l., $40^{\circ} \mathrm{NE}$, Calamagrostietum villosae, humic regosol*

\begin{tabular}{lllllllll} 
A & $0-22$ & 10YR 3/2 & 10YR 2/2 & 40 & n.a. & 4.0 & 13.65 & 7.33 \\
AC1 & $22-40$ & 10YR 5/3 & 10YR 3/4 & 50 & L & 4.9 & 8.52 & 5.23 \\
AC2 & $40-70$ & 10YR 5/3 & 10YR 3/3 & 85 & SL & 5.2 & 7.81 & 3.46 \\
\hline
\end{tabular}

10. Jaferowy Grzbiet, $1600 \mathrm{~m}$ a.s.l, $70^{\circ} \mathrm{SSW}$, vegetation with a predominance of high-mountain acidophilic rocky grasslands and tall-herb and tall-grass elements, umbrisol*

\begin{tabular}{lllllllll} 
A1 & $0-10$ & 10YR 4/2 & 10YR 3/2 & 0 & n.a. & 4.3 & 15.44 & n.a. \\
A2 & $10-23$ & 10YR 4/2 & 10YR 3/2 & 10 & n.a. & 4.1 & 8.00 & 2.8 \\
A3 & $23-37$ & 10YR 4/3 & 10YR 3/3 & 15 & LS & 4.5 & 6.17 & 2.1 \\
AC & $37-47$ & 10YR 5/4 & 10YR 4/4 & 40 & LS & 4.6 & 5.37 & 2.1 \\
\hline
\end{tabular}

11. Kalatówki, $1175 \mathrm{~m}$ a.s.l., $10^{\circ} \mathrm{ESE}$, fresh meadow with a predominance of elements from Gladiolo-Agrostietum, umbrisol*

\begin{tabular}{lllllllll} 
A1 & $0-16$ & 10YR 3/3 & 10YR 3/2 & 15 & n.a. & 4.1 & 7.62 & 34.7 \\
A2 & $16-33$ & 10YR 4/3 & 10YR 4/2 & 40 & LS & 4.4 & 3.86 & 24.7 \\
BwC & $33-52$ & 10YR 6/6 & 10YR 5/6 & 70 & LS & 4.6 & 1.83 & 25.6 \\
\hline
\end{tabular}

12. Goryczkowa Czuba, $1875 \mathrm{~m}$ a.s.l, $15^{\circ} \mathrm{E}$, Calamagrostietum villosae, umbrisol*

\begin{tabular}{lllllllll} 
O & $0-7$ & $7.5 Y R ~ 3 / 2$ & $7.5 Y R 2 / 1$ & 5 & n.a. & 4.2 & 23.12 & 4.8 \\
A1 & $7-37$ & 10YR 4/2 & 10YR 3/2 & 15 & S & 4.7 & 9.51 & 1.0 \\
A2 & $37-50$ & 10YR 4/2 & 10YR 2/2 & 10 & S & 4.7 & 9.87 & 1.4 \\
\hline
\end{tabular}

13. Mała Koszysta, 2070 m a.s.l., $15^{\circ} \mathrm{NW}$, Oreochloo distichae-Juncetum trifidi, umbrisol*

\begin{tabular}{lllllllll} 
A & $0-15$ & 10YR 3/2 & 10YR 2/1 & 40 & n.a. & 4.5 & 9.17 & 1.9 \\
AC1 & $15-27$ & 10YR 3/3 & 10YR 2/2 & 80 & LS & 4.7 & 6.55 & 0.8 \\
AC2 & $27-45$ & 10YR 4/3 & 10YR 3/2 & 85 & LS & 4.9 & 5.00 & 0.7 \\
\hline
\end{tabular}

Explanation: * according to SGP; n.a. - not analyzed; SOC - soil organic carbon; BS - base saturation

belonging to umbrisols - according to SGP, 12 were included in Umbrisols and 2 in Umbric Podzols units - according to WRB.

\section{Conclusions}

In the Tatras soils with umbric horizon (WRB 2015) occur usually above the upper timberline and on acid parent material. We compared the taxonomic positions of such soils classified according to WRB (2015) and the sixth edition of the Polish Soil Classification (SGP 2019). Since SGP6 (2019) adopted stricter criteria for the umbric horizon than WRB (2015) and the supremacy of this horizon in the key to determining soil units, we established that different types and subtypes of the studied soils (defined according to SGP6 2019), were found in Umbric Leptosols, Umbric Podzols and Umbrisols groups (WRB 2015). Thus, typical and humic rankers were classified to Leptosols, podzolic umbrisols and humic latent podzolic soils to 
Podzols and umbrisols and humic regosols to Umbrisols. In turn, the subtype umbrisols (SGP 2019) includes soils which according to WRB (2015) belong to both Umbrisols and Umbric Podzols.

According to SGP (2019) umbrisols constitutes a subtype in the type of gray soils which, in our opinion, is not in line with former classifications. Therefore we proposed to give umbrisols a rank of type in the order of black soils.

\section{References}

Balaceanu, V., Spirescu, M., Marian, E., Risnoveanu, I., Craciun, C., Grigorescu, A., Damian, M., 1987. Contributions to the knowledge of the mountain acid black soils Romania. Analele Institutului de Cercetari pentru Pedologie si Agrochimie (Romania) 47, 93-103.

Barannyk, A.V., 2016. Features of the formation of humus profile of mountainous meadowy brown soils (Cambic Umbrisols) of the Chornogora array of the Ukrainian Carpathians. Scientific Bulletins of the Belgorod State University. Series: Natural Science 37(25), 103-113. (in Ukrainian with English abstract)

Bedrna, Z., 2009. Soils with umbric horizon in Slovakia. Phytopedon (Bratislava) $8,70-80$.

Bedrna, Z., Dlapa, P., Ďuriš, M., Bủtorová, J., 2009. Umbrizem - a new soil type in Slovakia. Geographical Journal 61(4), 291-300.

Bedrna, Z., Dlapa, P., Šimkovic, I., Šimonovičová, A., 2010. Soils with umbric horizon in Slovakia. Comenius University in Bratislava: 226 pp. (in Slovak with English abstract)

Bedrna, Z., Račko, J., 2000. Contribution to pedogeography of the Belianske Tatry Mts. Geografický Casopis 52(4), 323-336. (in Slovak with English abstract)

Chodorowski, J., Melke, J., Ziółek, M., Uziak, S., 2012. The content of phosphorus in mountain meadow (polonina) soils as an indicator of past shepherding activity. Ekológia (Bratislava) 31(1), 54-64. http://doi. org/:10.4149/ekol_2012_01_54

Classification of Forest Soils in Poland - Klasyfikacja gleb leśnych Polski, 2000. Praca zbiorowa. Wydanie III PTG. CILP. Warszawa. (in Polish)

Dlapa, P., Bedrna, Z., Ďuriš, M., Kořenková, L., 2010. Importance of soil with umbric horizon for landscape in Slovakia. [In:] Barančoková, M., Krajčí, J., Kollár, J., Belčáková, I. (Eds.), Landscape ecology - methods, applications and interdisciplinary approach. Institut of Landscape Ecology, Slovak Academy of Science in Bratislava. Tatraprint Svit, 849-854.

Drewnik, M., 2008. Geomorfologiczne uwarunkowania rozwoju pokrywy glebowej w obszarach górskich na przykładzie Tatr. Wydawnictwo UJ, Kraków, 118 pp. (in Polish with English abstract)

FAO, 2006. Guidelines for Soil Description. Fourth edition, FAO, Rome.

Florea, N., Munteanu, I., Rusu, C., Dumitru, M., Ianoş, G., Răducu, D., Rogobete, G., Tărău, D., 2012. Romanian System of Soil Taxonomy. Sitech Publishing House, Craiova, Romania, 206 pp. https://doi.org/10.2136/ sh12-01-0006

Hudec, M., Hreško, J., 2013. Identification of umbric horizons in alpine levels of the Low Tatras. Phytopedon (Bratislava) 12(2), 5-9.

IUSS Working Group WRB, 2015. World Reference Base for soil resources 2014, update 2015. International soil classification system for naming soils and creating legends for soil maps. FAO. Rome, Italy, 203 pp.

Jenčo, M., Matečný, I., Putiška, R., Burian, L., Tančárová, K., Kušnirák, D., 2018. Umbrisols at Lower Altitudes, Case Study from Borská lowland (Slovakia). Open Geosciences 10, 121-136. https://doi.org/10.1515/geo2018-0010

Kabała, C. et al., 2019. Polish Soil Classification, $6^{\text {th }}$ edition - principles, classification scheme and correlations. Soil Science Annual 70(2), 71-97. https://doi.org/10.2478/ssa-2019-0009
Lityński, T., Jurkowska, H., Gorlach, E., 1976. Analiza chemiczno-rolnicza. PWN, Warszawa, 332 pp. (in Polish)

Miechówka, A., 2000. Charakterystyka tatrzańskich gleb nieleśnych wytworzonych ze skał węglanowych. Zeszyty Naukowe AR w Krakowie, Rozprawy 263, 86 pp. (in Polish with English abstract)

Miechówka, A., Drewnik, M., 2018. Rendzina soils in the Tatra Mountains, central Europe - a review. Soil Science Annual 69(2), 88-100. https:// doi.org/10.2478/ssa-2018-0009

Musielok, Ł., Kacprzak, A., Opyrchał, J., 2013. Właściwości i pozycja systematyczna gleb rozwiniętych na ryolitach w Górach Kamiennych. Prace Geograficzne 135, 21-39. (in Polish with English abstract) https://doi.org/10.4467/20833113PG.13.021.1549

Musielok, Ł., Drewnik, M., Szymański, W., Stolarczyk, M., 2019. Classification of mountain soils in a subalpine zone - a case study from the Bieszczady Mountains (SE Poland). Soil Science Annual 70(2), 170-177. https://doi.org/10.2478/ssa-2019-0015

Oyama M., Takehara H., 1970. Revised Standard Soil Color Charts. Research Council for Agriculture, Forestry and Fisheries, Japan.

Polish Soil Classification - Systematyka gleb Polski, 1974. Roczniki Gleboznawcze - Soil Science Annual 25(1), 1-149. (in Polish with English abstract)

Polish Soil Classification - Systematyka gleb Polski, 1989. Roczniki Gleboznawcze - Soil Science Annual 40(3-4), 1-50. (in Polish with English abstract)

Polish Soils Classification - Systematyka gleb Polski, 2011. Roczniki Gleboznawcze - Soil Science Annual 62(3), 1-193. (in Polish with English abstract)

Polish Soil Classification - Systematyka gleb Polski, 2019. Polskie Towarzystwo Gleboznawcze, Komisja Genezy, Klasyfikacji i Kartografii Gleb. Wydawnictwo Uniwersytetu Przyrodniczego we Wrocławiu, Polskie Towarzystwo Gleboznawcze, Wrocław-Warszawa, 290 pp. (in Polish with English abstract)

Polish Standard, 1998. Soil and mineral soil materials - sampling and determination of particle size distribution. In: PN-R-04032. Polish Committee for Standardizations, Warszawa.

Sanesi, G., Certini, G., 2005. The umbric epipedon in the N Apennines, Italy - an example from the Vallombrosa Forest. Journal of Plant Nutrition and Soil Science 168(3), 392-398. https://doi.org/10.1002/ jpln.200421651

Skiba, S., 2014. Gleby Doliny Suchej Wody w Tatrach. [In:] Rączkowska, Z., Kotarba, A. (Eds.), Dolina Suchej Wody w Tatrach. Środowisko i jego współczesne przemiany. Prace Geograficzne 239, 109-126. (in Polish with English abstract)

Societas pedologica slovaca, 2014. Morfogenetický klasifikačný system pôd Slovenska. Bazálna referenčná taxonómia (Morphogenetic Soil Classification System of Slovakia. Bazal Reference Taxonomy). The second revised edition. NPPC-VÚPOP, Bratislava, $96 \mathrm{pp}$. (in Slovak)

Tan, K.H., 2005. Soil sampling, preparation and analysis. Taylorand Francis Group, Boca Raton. https://doi.org/10.1201/9781482274769

Turrión, M.B., Schneider, K., Gallardo, J.F., 2009. Carbon accumulation in Umbrisols under Quercus pyrenaica forests: Effects of bedrock and annual precipitation. Catena 79, 1-8. https://doi.org:10.1016/ j.catena.2009.04.004

Vasiliniuc, I., Ursu, A., Niacşu, L., 2010. Soil cover transitions in the Vrancea region. Factori şi Procese Pedogenetice din Zona Temperată 9 S. nouă, 99-118.

Zadrożny, P., Miechówka, A., Nicia, P., 2007. Zawartość i rozmieszczenie siarki siarczanowej w profilach tatrzańskich gleb bielicoziemnych. Zeszyty Problemowe Postępów Nauk Rolniczych 520, 571-578. (in Polish with English abstract)

Zadrożny, P., Miechówka, A., 2008. Bielicowanie jako czynnik warunkujący rozmieszczenie siarki w profilu glebowym. Roczniki Gleboznawcze - Soil Science Annual 59(3-4), 298-301. (in Polish with English abstract) 
Klasyfikacja nieleśnych gleb górskich z poziomem umbric na przykładzie gleb tatrzańskich

\section{Słowa kluczowe}

Klasyfikacja gleb Poziom umbrik Umbrisole

Biotopy nieleśne Tatry

\section{Streszczenie}

W glebach biotopów nieleśnych Tatrzańskiego Parku Narodowego wytworzonych z kwaśnych utworów macierzystych, w piętrach klimatycznych bardzo chłodnym i umiarkowanie zimnym bardzo często występują poziomy, spełniające kryteria przyjęte dla poziomu diagnostycznego umbric. W pracy porównano pozycję taksonomiczną gleb biotopów nieleśnych Tatrzańskiego Parku Narodowego z poziomem umbric według klasyfikacji World Reference Base for Soil Resources z 2015 roku (WRB) i szóstego wydania Systematyki gleb Polski z 2019 roku (SGP). W SGP przyjęto nadrzędność poziomu umbrik w kluczu do oznaczania jednostek gleb oraz inne niż w WRB kryterium miąższości dla tego poziomu ( $\geq 30 \mathrm{~cm}$ ). Konsekwencją tego jest udział różnych typów i podtypów badanych gleb, określonych według SGP, w grupach gleb należących według WRB do: Umbric Leptosols, Umbric Podzols i Umbrisols. W grupie Leptosols znalazły się rankery typowe i próchniczne, w grupie Podzols umbrisole bielicowe i gleby skrytobielicowe próchniczne, a w grupie Umbrisols umbrisole i regosole próchniczne. Zaproponowano, aby wprowadzić do systematyki gleb Polski w rzędzie gleby czarnoziemne typ umbrisole. Obecnie, w SGP, umbrisole stanowią jeden z podtypów gleb szarych, należących do rzędu gleby czarnoziemne. Zasugerowano również aby do podtypu rankery próchniczne zaliczyć rankery, w których sumaryczna miąższość poziomów Oh (nie spełniających kryterium miąższości dla folika) i A wynosi $20 \mathrm{~cm}$ lub więcej. 